\title{
MEMBACA KEARIFAN LOKAL DALAM PENGGUNAAN MEDIA SOSIAL
}

\author{
Errika Dwi Setya Watie \\ Program Studi Ilmu Komunikasi \\ Fakultas Teknologi informasi dan komunikasi \\ Universitas Semarang \\ errika@usm.ac.id
}

\begin{abstract}
Media sosial membawa pada perubahan cara berinteraksi antar individu dan perubahan cara penyebaran informasi di masyarakat. Media sosial juga membawa kebebasan individu dalam mengemukakan pendapat dan berinteraksi. Namun sayangnya, kebebasan yang dihadirkan melalui media sosial membawa pada terancam luruhnya kearifan lokal yang ada.

Hadirnya kearifan lokal sebenarnya akan menjadi penyeimbang untuk pesatnya perkembangan teknologi informasi dan komunikasi. Sehingga dengan demikian, gerakan nyata dari para pihak yang terkait media sosial perlu untuk dilakukan, salah satunya melalui gerakan literasi media sosial. Literasi media sosial perlu dilakukan agar kehidupan sosial tetap terjaga dengan harmonis dan tetap mampu mengikuti perkembangan jaman.
\end{abstract}

Keywords : media sosial, kearifan lokal

\section{PENDAHULUAN}

Perkembangan teknologi informasi dan komunikasi dewasa ini menunjukkan perubahan yang cepat dan drastis, terutama di ranah perkembangan media komunikasi massa. Sebagaimana yang kita tahu, media komunikasi massa memiliki perkembangan yang cukup signifikan. Dimulai dari menjamurnya media lokal, berkembangnya media online, hingga populernya media sosial di berbagai kalangan masyarakat.

Perkembangan media sosial di Indonesia, tak lepas pula dari budaya masyarakat Indonesia yang komunal.
Kebiasaan masyarakat Indonesia untuk berkumpul dan berhimpun membuat perkembangan media sosial makin pesat di Indonesia. Dimulai sejak hadirnya berbagai media blogging, kemudian hadir Friendster, Facebook, Twitter, hingga kini makin banyak ragam media sosial yang hadir dan digunakan masyarakat Indonesia, dengan berbagai fitur keunggulan yang ditawarkan. Sebagai gambaran, berdasarkan survey yang dilakukan semiocast tahun 2012, Indonesia menempati peringkat kelima dunia sebagai negara pengguna Twitter terbesar, yaitu sebesar 19.5 juta pengguna dibawah Inggris yang sebesar 23.8 juta pengguna. (http://netpreneur.co.id/7-cara-mudahpromosi-di-twitter/\#.VYy9MPkkFpk, diunduh Juni 2015). Data ini pun diyakini terus meningkat, mengingat menurut survey Nielsen, yang dikutip sosmedtoday.cm, pengguna internet di Indonesia tahun 2014 mencapai kisaran 70 juta pengguna (http://sosmedtoday.com/2014/09/penggunainternet-2014-berapa-data-nielsen/, diunduh juni 2015).

Bertambahnya jumlah pengguna internet di Indonesia yang makin pesat ini, didorong salah satunya dengan akses internet yang makin mudah dan murah, serta kepemilikan perangkat pendukung yang semakin mudah. Perkembangan jumlah pengguna Internet ini, terutama media sosial, tentunya merupakan kabar gembira bagi persebaran informasi diantara masyarakat Indonesia. Namun, sebagaimana diketahui, perkembangan teknologi tentunya tidak saja membawa dampak yang positif, namun juga dampak yang negatif. Hal inilah yang 
hendaknya disadari oleh para penggerak dan pengguna media, agar nilai positif yang didapat bisa lebih kuat dibanding nilai negatif.

\section{PEMBAHASAN}

Media baru sebagai wadah media sosial, menurut Flew menjadi media media yang menarik karena menawarkan kemampuan interaktifitas yang tinggi bagi para penggunanya. Kehadiran media sosial sebagai bagian dari media baru dengan segala kemudahannya akhirnya membawa pada gaya berkomunikasi yang baru. Kondisi ini dimungkinkan karena penggunanya memiliki kebebasan dalam memilih dan menyebarkan informasi. Kebebasan menyebarkan dan mengkonsumsi informasi inilah yang kemudian merubah konsep sentral komunikasi lewat media, dimata masyarakat. Perubahan cara berkomunikasi lewat media ini akhirnya memunculkan fenomena virtual community dan virtual identity. Kebebasan yang dirasanya pengguna media sosial memungkinkan pengguna untuk menciptakan komunitas virtual dan identitas virtual, yang sangat mungkin berbeda dari apa yang dimilikinya di dunia nyata (Flew, 2002: 11-25).

Dalam dunia virtual, pengguna media sosial bisa menjadi siapa saja, bisa berhubungan dengan siapa saja, dan dimungkinkan berkomunikasi dengan siapa saja. Disinilah ranah komunikasi massa terbentuk dalam media sosial. Namun, disaat yang sama komunikasi antar pribadipun juga terbentuk. Saat pengguna saling berkomentar disinilah ranah komunikasi pribadi terwujud (Utari, 2011:52-53). Interaksi yang ada dan besarnya terpaan dalam media sosial, membuat seseorang bisa secara sadar ataupun tak sadar menyesukaikan diri dengan bentukan terpaan informasi yang muncul di hadapannya. Christoper Wulf dalam artikelnya "The Temporaly of World-View dan Self Image, mengatakan bahwa gambaran yang disajikan media, akan menjadi cermin tempat penggunanya berkaca
(Piliang, 2004:166-167). Kehadiran dunia virtual semakin mengukuhkan gambaran yang dibentuk ini.

Kebebasan yang ditawarkan internet terutama dalam hal ini media sosial, seolah membuat matinya kepekaan etika. Apa yang harusnya tidak dilakukan, menjadi "nampak wajar" dilakukan. Bahkan tak jarang ada yang menganggapnya bukan suatu kesalahan dengan berbekal berbagai pembenaran yang dimunculkan. Etika yang banyak dilanggar saat ini adalah etika budaya. Mead dalam West dan Turner berpendapat bahwa konsep diri yang dimiliki tiap individu, membawa pada mekanisme bagaimana individu tersebut berinteraksi. Mekanisme terkait konsep diri ini digunakan untuk menuntun perilaku dan sikap yang ditampilkannya (West \& Turner, 2008: 102-103). Permasalahan kemudian muncul ketika individu tersebut berhubungan dengan banyak pihak lain yang memiliki pengaruh yang masif. Dalam kondisi ini, individu bisa berubah konsep dirinya, menjadi konsep yang berbada walau secara tak sadar. Budaya yang selama ini turut membentuk konsep diri seseorang bisa luruh seiring dengan interaksi individu tersebut dengan latar budaya yang berbeda, sehingga juga akan sedikit banyak merubah konsep diri seseorang tersebut.

Darmastuti pada buku Komunikasi 2.0 mengatakan bahwa dasar dari budaya adalah komunikasi. Dua hal tersebut merupakan dua hal yang tak terpisahkan, yang saling mempengaruhi. Darmastuti juga menambahkan, bahwa komunikasi melalui media sosial akan mampu merubah seseorang dalam beberapa hal :

1. Kepercayaan, nilai, dan sikap

2. Pandangan dunia

3. Organisasi sosial

4. Tabiat manusia

5. Orientasi kegiatan

6. Persepsi diri dan orang lain

(Darmastuti, 2011: 225)

Fenomena yang saat ini muncul adalah kondisi pengguna media sosial yang lupa adanya etika budaya yang patut dipertimbangkan juga dalam berinteraksi di 
dunia maya. Kebebasan berbicara dan berekspresi rupanya telah membuat banyak pengguna media sosial lupa akan adanya kearifan lokal yang sebelumnya telah membentuk bagaimana konsep diri mereka dan bagaimana mereka berperilaku. Anak muda terutama sebagai pengguna media sosial banyak yang mulai alpa dalam mempertimbangkan kearifan lokal dalam berinteraksi di dunia media sosial. Banyak pengguna media sosial lupa, bahwa apapun yang diunggah dalam media sosial, baik gambar, video, suara, maupun teks, meskipun diarahkan secara personal kepada seseorang yang lain, tetap akan bisa dibaca oleh banyak orang lain.

Berdasarkan pengamatan penulis, tidak sedikit pengguna media sosial yang dengan mudahnya menggunakan kata-kata makian dalam status yang diunggahnya. Kata - kata yang tak akan digunakannya dan diucapkannya jika berhubungan dengan orang lain di dunia nyata. Dalam hal ini, mereka lupa kata makian tersebut adalah salah satu yang berdasar kearifan lokal tidak diperkenankan untuk diucapkan, apalagi di wilayah yang bisa dilihat banyak orang. Pengguna media sosial juga dengan mudah mengunggah berbagai gambar, baik gambar diri sendiri maupun orang lain, tujuannya tak lain hanya sekedar pamer, namun tidak lagi memikirkan nilai kepantasan akan gambar yang diunggah.

Kondisi seperti ini bisa meluruhkan kearifan lokal yang selama ini dipegang masyarakat, jika terus menerus dibiarkan. Sebab apa yang dilakukan terus menerus tanpa adanya koreksi jika salah, maka memungkinkan akan dianggap sebagai suatu kebenaran. Sebagai bukti, ketika penulis menanyakan secara sederhana kepada pengguna yang menggunakan kata-kata makian dalam unggah statusnya, apakah tidak merasa salah dalam melakukannya, reaksi yang didapat adalah mereka merasa hal tersebut wajar, karena ditujukan untuk teman mereka sendiri. Jawaban tersebut membuktikan mereka lupa bahwa apapun yang diunggahnya akan bisa dibaca dan disebarkan oleh banyak orang lain.

\section{PENUTUP}

Kearifan lokal sebenarnya ada dan hendaknya diperhatikan oleh setiap individu yang hidup dalam masyarakat lokal. Tidak ada orang yang lepas sepenuhnya dari adanya kearifan lokal dimana orang tersebut hidup. Indonesia sebagai negara dengan kekayaan budaya yang tinggi, tentunya memiliki kearifan lokal yang kuat pula. Adat jawa misalnya, membawa kearifan lokal yang kuat bagi masyarakatnya. Adat dan nilai kesopanan pada suku Jawa menuntut salah satunya penggunaan gaya bahasa yang disesuaikan dengan kepada siapa orang tersebut berinteraksi dan dimana seseorang berinteraksi.

Kehadiran media sosial, memang telah membawa angin segar pada perkembangan gaya komunikasi individu, serta membawa pencerahan pada penyebaran informasi. Namun ternyata kebabasan yang ditawarkan media sosial membawa cara komunikasi yang justru bisa mengorbankan kearifan lokal. Padahal kearifan lokal hadir sebagai penyeimbang akan adanya perkembangan teknologi informasi dan komunikasi.

Apa yang kemudian bisa dilakukan, tentunya paper ini hendaknya tidak hanya berhenti di sekedar tulisan belaka, namun diharapkan menjadi pemecut gerakan nyata dalam bentuk literasi media sosial dari segenap pihak yang terlibat, dari sis akademisi, tokoh masyarakat, penggerak media sosial, hingga pengguna media sosial. Diharapkan literasi media sosial yang terbangun tersebut, mampu membawa pada kesadaran kebebasan seperti apa yang hendaknya bisa terbangun seiring dengan perkembangan teknologi informasi yang ada. 


\section{DAFTAR PUSTAKA}

[1]. Flew, Terry, "New Media: An Introduction", Oxford University Press, New York, 2002.

[2]. Yasraf Amir Piliang, "Dunia Yang Dilipat", Jalasutra. Yogyakarta: Jalasutra, 2004

[3]. Prahastiwi Utari, "Media Sosial, New Media dan Gender dalam Pusaran Teori Komunikasi", Divisi Litbang Aspikom, Komunikasi 2.0: Teoritisasi dan Implikasi, Mata Padi Pressindo, Yogyakarya, 2011.

[4]. Rini Darmastuti, "Media Sosial dan Perubahan Budaya", Divisi Litbang Aspikom, Komunikasi 2.0: Teoritisasi dan Implikasi, Mata Padi Pressindo, Yogyakarya, 2011.

[5]. West, Richard \& Turner, Lynn H., "Pengantar Teori Komunikasi:Analisis dan Aplikasi (Introduction Communication Theory: Analysis and Application", Salemba Humanika, Jakarta. 2008.

[6]. http://netpreneur.co.id/7-cara-mudahpromosi-di-twitter/\#.VYy9MPkkFpk, diunduh Juni 2015.

[7]. http://sosmedtoday.com/2014/09/pengg una-internet-2014-berapa-data-nielsen/, diunduh Juni 2015. 